\title{
Kalendarium I wojny światowej
}

\author{
|Aleksandra Kosicka-Pajewska
Uniwersytet im. Adama Mickiewicza
}

\section{ROK 1914}

\section{8 czerwca}

W Sarajewie, stolicy Bośni, w zamachu zginął następca tronu monarchii habsburskiej, arcyksiążę Franciszek Ferdynand wraz z żoną księżną Zofią Hohenberg. Zabójcą arcyksięcia był student serbski Gavrilo Princip, choć w zamachu udział brali także Nedeljko Čabrinović i Trifko Grabež. Inspiracja zamachu wyszła od oficerów i organizacji „Czarna Ręka”. Zamachowcy skazani zostali za swój czyn na lat dziesięć więzienia 29 października 1914 (żaden z zamachowców w chwili popełnienia czynu nie miał ukończonych lat dwudziestu, według obowiązującego kodeksu karnego nie można ich było skazać na dłuższą karę, bowiem byli nieletnimi. Wszyscy trzej zmarli $\mathrm{w}$ więzieniu podczas toczącej się wojny).

\section{5 lipca}

Doręczenie przez ambasadora Austro-Węgier w Berlinie, hr. Laszlo Szögyenyi-Marich, odręcznego listu Franciszka Józefa cesarzowi Wilhelmowi z pytaniem, czy monarchia może liczyć na poparcie Niemiec.

\section{7 lipca}

Berlin zapewnia Franciszka Józefa w liście o „bezwzględnym poparciu” oraz że Niemcy "stoją u boku monarchii jako sprzymierzeniec i przyjaciel”.

\section{9 lipca}

Cesarz Franciszek Józef wyraził zgodę na stanowcze i ostre kroki wobec Serbii.

\section{9 lipca}

Posiedzenie Rady Ministrów Spraw Wspólnych, na którym zatwierdzono notę do rządu serbskiego. Określono cel wojenny Austro-Węgier 
- zmiażdżenie całkowite Serbii, część terytorium Serbii miałaby być odstąpiona Bułgarii, Grecji, Albanii, a także ewentualnie Rumunii; konwencja wojenna miałaby uzależnić Serbię od monarchii Austro-Węgierskiej; usunięcie dynastii Karadziordziewiczów.

\section{3 lipca}

Czwartek, godz. 18, poseł c. i k. w Belgradzie, generał kawalerii, baron Vladimir Giesl von Gieslingen złożył notę Austro-Węgier na ręce ministra skarbu Lazara Pacu, zastępującego nieobecnego premiera Serbii, Nikoli Pašicia. Żądania dotyczyły: potępienia antyaustriackiej propagandy w Serbii; ukarania wszystkich urzędników i oficerów, którzy brali w niej udział; deklaracji o nieangażowaniu się w jakiekolwiek sprawy narodów wchodzących w skład monarchii Austro-Węgierskiej (zwłaszcza terytorialne) wszczęcie śledztwa przeciwko zamachowcom na arcyksięcia Franciszka Ferdynanda, w którym braliby udział członkowie rządu Austro-Węgierskiego. Termin 48-godzinnego ultimatum upływał 25 lipca o godzinie 18.

\section{5 lipca}

Premier Serbii Nikola Pašić przybył osobiście, w sobotę, do poselstwa austriackiego z odpowiedzią serbską na notę austriacką. Serbia część warunków przyjmuje, odrzuca te, które godzą w suwerenność państwową. Odpowiedź serbska kończyła się słowami: „gdyby rząd cesarski i królewski nie był usatysfakcjonowany, rząd serbski gotów jest przyjąć rozwiązanie pokojowe i oddać sprawę Trybunałowi Haskiemu bądź wielkim mocarstwom”.

\section{8 lipca}

Austro-Węgry wypowiadają wojnę Serbii.

\section{9 - 30 lipca}

Początek powszechnej mobilizacji w Rosji (bez konsultacji z sojuszniczą Francją).

\section{9 lipca}

Uchwała rządu Wielkiej Brytanii o „ostrożnej mobilizacji” floty brytyjskiej.

\section{9 lipca}

Flota brytyjska stanęła w ostrym pogotowiu, by przeprowadzić daleką blokadę Niemiec, celem zamknięcia Niemcom wyjść na oceany. Były dwa wyjścia: południowe, przez kanał La Manche i północne, pomiędzy Szetlandami a Norwegią.

\section{0 lipca}

Początek mobilizacji w krajach monarchii Habsburgów.

\section{1 lipca}

Wizyta ambasadora niemieckiego barona Wilhelma von Schön u prezesa ministrów i ministra spraw zagranicznych Francji Rene Vivianiego 
z zapytaniem, czy w razie wybuchu wojny niemiecko-rosyjskiej Francja zachowa neutralność. Odpowiedzi nie uzyskał.

\section{1 sierpnia}

Niemcy wypowiadają wojnę Rosji; Niemcy zarządzają powszechną mobilizację. Bieg lipcowych wypadków doprowadził do konfliktu Niemiec z Rosją, ale nie wywołał żadnych zatargów z Francją.

\section{1 sierpnia}

Zarządzenie powszechnej mobilizacji we Francji.

\section{2 sierpnia}

Wojska niemieckie bez wypowiedzenia wojny wkroczyły na terytorium Wielkiego Księstwa Luksemburga.

\section{2 sierpnia}

Podpisanie tajnego porozumienia między Turcją i Niemcami.

\section{3 sierpnia}

Niemcy wypowiadają wojnę Francji.

\section{3 sierpnia}

Holandia ogłosiła neutralność. Rozpoczęcie mobilizacji w Szwajcarii.

\section{4 sierpnia}

Wojska niemieckie przekroczyły granice Belgii, bez wypowiedzenia wojny. Szwecja ogłosiła neutralność. Norwegia ogłosiła neutralność. Hiszpania ogłosiła neutralność.

\section{4 na 5 sierpnia}

Wielka Brytania wypowiada wojnę Niemcom. Stany Zjednoczone Ameryki Północnej ogłaszają neutralność. Niemcy uderzyli na twierdzę Liège, która uchodziła za jedną z lepiej ufortyfikowanych w Europie. Zdobyli ją dopiero 16 sierpnia; silna obrona Belgów.

\section{6 sierpnia}

Austro-Węgry wypowiadają wojnę Rosji. Serbia wypowiada wojnę Niemcom. Chiny ogłaszają neutralność. Jeszcze przed zakończeniem mobilizacji Niemcy rozpoczęli wielki marsz na Francję.

\section{7 sierpnia}

Francuzi przystąpili do działań wojennych w Alzacji. Portugalia ogłosiła solidarność z Wielką Brytanią.

\section{8 sierpnia}

Francuzi bez oporu Niemców zajęli Miluzę. 10 sierpnia Niemcy przystąpili do kontrataku i wyparli Francuzów z Miluzy. 


\section{1 sierpnia}

Francja wypowiedziała wojnę Austro-Węgrom.

\section{2 sierpnia}

Wielka Brytania wypowiedziała wojnę Austro-Węgrom. Półtora miliona żołnierzy niemieckich znajdowało się na terytorium Belgii i Francji.

\section{9 sierpnia}

Prezydent Woodrow Wilson wezwał Amerykanów, aby pozostali „bezstronni i w myślach, i w czynach".

\section{0 sierpnia}

Zdobycie Alzacji (z wyjątkiem miasteczka Hann) przez wojska niemieckie.

\section{3 sierpnia}

Japonia wypowiedziała wojnę Niemcom. Niemcy utworzyli Generałgubernatorstwo belgijskie z generał-gubernatorem Moritzem Ferdinandem von Bissingiem.

\section{3 sierpnia - 1 września}

Ofensywa austriacko-węgierska. Zwycięstwa pod Kraśnikiem, Zamościem, Komorowem.

\section{4 sierpnia}

Marszałek Joseph Joffre, wódz naczelny armii francuskiej, wydaje rozkaz odwrotu. Niemcy idą na Paryż.

\section{5 sierpnia}

Niemcy spalili dzielnicę uniwersytecką w Leuven (franc. Louvian) z najpiękniejszą i najbogatszą w Europie biblioteką.

\section{0 - 25 sierpnia}

„Bitwy graniczne” pomiędzy Skaldą a Wogezami, pomiędzy wojskami francuskimi i niemieckimi. Niemcy osiągnęli sukces taktyczny, ale nie powiodło się rozbicie armii francuskiej.

\section{6 sierpnia}

Rekonstrukcja rządu premiera Vivianiego we Francji. Ministrem spraw zagranicznych został Theophile Delcassé, do ministerstwa wojny dołączył Aléxsandre Millerand.

\section{6 - 30 sierpnia}

Bitwa pod Tannenbergiem. Armie niemieckie pokonały wojska rosyjskie. Ofensywa rosyjska w Prusach Wschodnich spowodowała, że część armii niemieckich przerzucono z frontu zachodniego. Bitwa o Lwów. Miasto zajmują Rosjanie 3 września. 


\section{6 sierpnia - 5 września}

Walki armii niemieckich: prawe skrzydło 1. i 2. Armia kierowały się na zachód, aby odeprzeć spodziewany atak od strony Paryża. 26 sierpnia 1. Armia pobiła Anglików pod Le Câteau, 28 i 29 sierpnia Francuzów pod Peronne. 2. Armia pokonała pod Saint-Quentin Francuzów.

\section{2 września}

Prezydent Francji wraz z rządem opuszczają Paryż, przenoszą się do Bordeaux.

\section{3 - 4 września}

1. i 2. Armia niemiecka przekroczyły Marnę. 2. Armia zajęła Reims.

\section{4 września}

Podpisanie w Londynie konwencji między Francją, Wielką Brytanią i Rosją, w której państwa te zobowiązują się, że nie zawrą z Niemcami separatystycznego pokoju.

\section{6 - 9 września}

Pierwsza bitwa nad Marną. Niemcy odnieśli znaczący sukces taktyczny, pokonując Francuzów pod Fère-Champenoise, zabrakło im jednak odwodów; tym samym utworzyła się pusta przestrzeń, w którą wdarły się wojska francuskie. 9 września Niemcy rozpoczęli odwrót. Bitwa nad Marną zakończyła się zwycięstwem Francuzów. Bitwa nad Marną była punktem zwrotnym w dziejach pierwszej wojny światowej. Przegrana przekreśliła Niemcom wojnę krótkotrwałą, otwarła wojnę długą, ponad czteroletnią, wyczerpującą dla obu stron.

\section{6 - 15 września}

Bitwa nad Jeziorami Mazurskimi. Armia rosyjska, tzw. Armia Niemen, ponosi olbrzymie straty i opuszcza Prusy Wschodnie.

\section{4 września - 17 listopada}

Na terytorium północno-wschodniej Francji toczyły się zażarte bitwy, zwane niekiedy „wyścigiem ku morzu”. Celem Niemiec było opanowanie wybrzeża kanału La Manche i zajęcia Calais i Dunkierki, aby odciąć Wyspy Brytyjskie od kontynentu.

\section{2 - 25 września}

Walki pod Verdun.

\section{9 paźdxiernika}

Generał Hans von Beseler zdobył Antwerpię. W ręce niemieckie wpadły: 1300 armat, wielkie zapasy amunicji, surowce: nafta, metale, wełna. Król Albert wycofuje wojska belgijsko-brytyjskie do Flandrii.

\section{1 - 15 października}

Zajęcie przez Niemcy Gandawy, 12 - Lille, 14 - Brugii, 15 - Ostendy i Nieuwpoort. Belgia do rzeki Ijzer zajęta była przez Niemcy. 


\section{1 października}

Wojska austriacko-węgierskie zdobywają Przemyśl.

\section{0 października - 3 listopada}

Ciężkie walki, tzw. pierwsza bitwa we Flandrii; toczyła się na wydartej morzu nizinie we mgle i w deszczu. Otwarcie przez Belgów śluzy pod Nieuwpoort przerwało walki.

\section{9 - 30 października}

Początek wojny rosyjsko-tureckiej. Flota turecka walczy u wybrzeża rosyjskiego Morza Czarnego.

\section{2 - 5 listopada}

Wypowiedzenie wojny Turcji przez Rosję, Wielką Brytanię i Francję.

\section{5 listopada}

Anektowanie Cypru przez Wielką Brytanię.

\section{7 listopada}

Porażka Turcji: zajęcie przez Anglików fortu Fao (obecnie Al-Fau) nad Zatoką Perską.

\section{0 - 24 listopada}

Druga bitwa we Flandrii, zwana bitwą pod Ypres. Wojska sprzymierzone stoczyły zaciekły bój z wojskami niemieckimi. Ofensywa została odparta z dużymi stratami w ludziach po obu stronach. Szczególnie wielkie straty ponieśli Niemcy, wśród nich kwiat uniwersyteckiej młodzieży - ochotnicy z Kinderregimenter (pułków dzieci). Była to ostatnia bitwa wojny ruchomej, a pierwsza wojny pozycyjnej aż do roku 1918. Niemcy opanowali Belgię i dziesięć departamentów Francji.

\section{3 listopada}

Sułtan-kalif wydał do muzułmanów całego świata proklamację, ogłaszając dżihad - wojnę świętą przeciwko niewiernym.

\section{6 listopada - 17 grudnia}

Bitwa pod Łodzią i Toruniem zakończona zajęciem tych miast przez Rosjan.

\section{8 grudnia}

Ogłoszenie przez Wielką Brytanię protektoratu nad Egiptem.

\section{ROK 1915}

\section{8 stycznia}

Japonia ogłasza „21 żądań” wobec Chin.

\section{2 stycznia}

Rozpoczęcie „ofensywy karpackiej”. Wojskom państw centralnych nie udało się przejść przez Karpaty. Ofensywa zatrzymała się w połowie lutego. Dopiero 22 marca kapitulował Przemyśl. 


\section{8 stycznia}

Rada Wojenna zarządziła „ekspedycję morską" dla zbombardowania półwyspu Gallipoli (Gelibolu) wraz z Konstantynopolem. Po raz pierwszy Niemcy na froncie wschodnim - pod Bolimowem - użyli gazów trujących. Efekt był minimalny ze względu na mróz, który udaremnił skutki działań gazu.

\section{4 lutego}

Początek wojny podwodnej. Oświadczenie rządu niemieckiego, że flota niemiecka nie będzie zatapiać statków państw neutralnych.

\section{7 - 8 lutego}

Zimowa bitwa nad Jeziorami Mazurskimi. 10. Armia niemiecka zmusiła do kapitulacji część wojsk rosyjskich w okolicach Puszczy Augustowskiej.

\section{6 lutego - 20 marca}

Bitwa zimowa w Szampanii. Odparcie ataków francuskich. Ofensywa angielska pod Neuve-Chapelle.

\section{9 lutego}

Uderzenie floty angielskiej i francuskiej na tureckie forty broniące Dardaneli; bez ich zdobycia.

\section{5 lutego}

Ponowny atak brytyjsko-francuski na forty Cieśnin. Zdobyto forty wejściowe. Turcy obronili brzegi.

\section{7 lutego}

Zakończenie ofensywy niemieckiej w Prusach Wschodnich.

\section{4 marca}

Minister spraw zagranicznych Rosji - Siergiej Sazonow - wysłał notę do ambasadorów Wielkiej Brytanii i Francji w Piotrogrodzie z określeniem celów wojennych Rosji na Bliskim Wschodzie.

\section{2 marca}

Rząd brytyjski przyjął postulaty rosyjskie w sprawie Konstantynopola. 12 kwietnia warunki przyjęła Francja z zastrzeżeniem, że między innymi Rosja zagwarantuje po „wsze czasy” pełną swobodę przejazdu przez cieśniny.

\section{2 kwietnia - 25 maja}

Druga bitwa pod Ypres. Niemcy wzmacniają swoje pozycje.

\section{4 kwietnia}

Wojsko i policja turecka na podstawie rozporządzenia rządu aresztowała, a następnie zamordowała w Stambule ponad 2300 osób pochodzenia ormiańskiego. Był to początek rzezi Ormian. Do końca 1915 roku zamordowano pół miliona, a do roku 1917 - 1,5 miliona osób mniejszości ormiańskiej. 


\section{6 kwietnia}

Podpisanie w Londynie porozumienia między Włochami i państwami Ententy. Włochy po wojnie miały otrzymać: Trydent, Tyrol cisalpiński do przełęczy Brenner, Triest, miasta Gorycję i Gradisko, Istrię, Dalmację z przylegającymi do niej wyspami i inne.

\section{9 kwietnia - 9 maja}

Niemieckie uderzenie na Litwę i Kurlandię.

\section{2 maja}

Austriacy i Niemcy natarli na Gorlice, przełamali front i wyparli Rosjan z Galicji, Bukowiny, Podkarpacia.

\section{Maj}

Przystąpienie Włoch do wojny przeciwko monarchii habsburskiej.

\section{3 czerwca}

Zajęcie Przemyśla przez Niemców i Austriaków.

\section{2 czerwca}

Zdymisjonowano ministra wojny, generała kawalerii Władimira Suchomlinowa. Został oskarżony o nadużycia władzy, łapownictwo i - co najważniejsze - zdradę stanu. W kwietniu 1917 roku został skazany na dożywotnią katorgę.

\section{2 czerwca}

Wkroczenie wojsk austriackich i niemieckich do Lwowa.

\section{3 czerwca - 7 lipca}

Pierwsza bitwa nad Isonzo na froncie włosko-austriackim (ogółem było ich jedenaście - do roku 1917). Bitwy jesienne 1915 roku nie przyniosły rozstrzygnięcia.

\section{3 lipca}

12. Armia niemiecka po ciężkich walkach przerwała front rosyjski dookoła Przasnysza.

\section{9 lipca}

Niemcy stanęli nad Narwią.

\section{4 lipca}

Niemcy opanowali przyczółki mostowe w Pułtusku i Różanie.

\section{0 lipca}

Niemcy, 11. Armia oraz 2. i 4. Armia austro-węgierska zajęły Lublin.

\section{1 sierpnia}

Niemcy i Austro-Węgry zajęły Chełm.

\section{4 sierpnia}

Niemcy i Austro-Węgry zajęły Dęblin. 


\section{5 sierpnia}

Wysadzenie przez armię niemiecką mostów na Wiśle w Warszawie. Wejście Niemców do Warszawy.

\section{5 sierpnia}

Ustanowienie niemieckiej administracji w północnej części Królestwa Polskiego. Generał-gubernatorem został Hans von Beseler, siedzibą - Warszawa. Generał-gubernatorem w południowej części został generał austriacki Kuk; siedzibą - Lublin.

\section{5 września}

Naczelnym Wodzem armii rosyjskiej zostaje ponownie car, osobiście. Odwołano tym samym Wielkiego Księcia Mikołaja Mikołajewicza z tej funkcji.

\section{2 września - 6 października}

Ofensywa wojsk francuskich i angielskich w Szampanii, pod dowództwem naczelnego wodza armii francuskiej generała Josepha J. Joffra, zakończona niepowodzeniem.

\section{6 października}

Ofensywa niemiecko-austriacka przeciw Serbii.

\section{7 października}

Wojska Państw Centralnych przeszły Dunaj i Sawę.

\section{9 października}

Zdobycie Belgradu.

\section{1 października}

Bułgaria przystąpiła do Państw Centralnych.

\section{4 października}

Bułgaria wypowiedziała wojnę Serbii. Turcja wypowiedziała wojnę Serbii.

\section{5 - 20 października}

Państwa sprzymierzone wypowiadają wojnę Bułgarii.

\section{6 - 7 grudnia}

Zgoda lorda Kitchenera na tymczasowe zatrzymanie wojsk Wielkiej Brytanii i Francji w Salonikach, po nieudanych próbach zdobycia Dardaneli.

\section{ROK 1916}

\section{7 stycznia}

Wznowienie, po półtorarocznej przerwie, linii kolejowej łączącej bezpośrednio Berlin z Konstantynopolem.

\section{1 lutego - koniec czerwca}

Uderzenie niemieckie pod Verdun. Zdobycie twierdzy miało Niemcom przynieść sukces propagandowy, militarny i moralny; Francuzów miało 
rzucić na kolana i doprowadzić do pokoju z Wielką Brytanią. Twierdza była źle przygotowana do ciężkich walk. Były cztery fazy najdłuższej bitwy w dziejach dotychczasowych wojen. W bitwie pod Verdun zginęło około 700 tys. żołnierzy z obu stron.

\section{4-30 kwietnia}

Konferencja w Kienthalu. Mobilizacja międzynarodowego ruchu robotniczego przeciwko wojnie imperialistycznej.

\section{Maj}

Wielka Brytania uznała porozumienie francusko-rosyjskie, a Rosja francusko-brytyjskie. Układ trójstronny zastąpił dotychczasowy układ dwustronny.

\section{1 maja - 1 czerwca}

Bitwa morska pod Skagerrakiem u wybrzeży Jutlandii. Była to jedyna wielka bitwa morska podczas I wojny światowej.

\section{6 - 22 czerwca}

Blokada Grecji.

\section{1 czerwca}

Ultimatum Ententy z żądaniem przeprowadzenia demilitaryzacji Grecji oraz rekonstrukcji rządu.

\section{4 czerwca}

Wojska francuskie i brytyjskie rozpoczęły wielką ofensywę nad Sommą. Walki nad Sommą nazwano pierwszą bitwą materiałową. „Technika wypowiedziała wojnę strategii”, a „człowiek stał się sługą maszyny”; do walki sprzymierzeni wprowadzili czołgi. Według oceny wodza naczelnego wojsk francuskich, ofensywa nad Sommą spełniła swój cel - osłabiła ataki niemieckie na Verdun. Bitwa nad Sommą ocaliła Verdun.

\section{3 lipca}

Porozumienie Rosji z Japonią.

\section{8 lipca}

Uderzenie wojsk rosyjskich w Galicji Wschodniej i na Bukowinie. Zdobyli: Brody, Halicz, Stanisławów.

\section{7 sierpnia}

W Bukareszcie podpisano układ polityczny i konwencję militarną pomiędzy Rumunią i Państwami Koalicji. Układ stanowił, że Rumunia wypowie wojnę Austro-Węgrom, w zamian Koalicja gwarantowała jej integralność terytorialną oraz powiększenie królestwa przez włączenie Siedmiogrodu, Banatu, Bukowiny. 


\section{8 sierpnia}

Ferdynand I, król Rumunii, wypowiedział wojnę Austro-Węgrom. Niemcy wypowiadają wojnę Rumunii.

\section{0 sierpnia}

Turcja wypowiedziała wojnę Rumunii.

\section{1 września}

Bułgaria wypowiedziała wojnę Rumunii.

\section{2 września}

Nowy naczelny wódz armii niemieckiej, Hindenburg, wydał rozkaz wstrzymania ataków twierdzy Verdun. Plan Falkenhayna zakończył się całkowitym niepowodzeniem.

\section{5 listopada}

Proklamowanie aktu 5 listopada przez generał-gubernatorów Beselera i Kuka, czyli wolę cesarzy w sprawie utworzenia „samodzielnego” Królestwa Polskiego. Celem aktu było pozyskanie społeczeństwa polskiego do walki przeciwko Rosji.

\section{5 listopada}

Obrady konferencji szefów lub przedstawicieli rządów państw Koalicji. Celem była analiza sytuacji na froncie.

\section{1 listopada}

Zmarł cesarz Franciszek Józef.

\section{2 grudnia}

Wręczenie przez Niemcy noty z propozycją pokojową przedstawicielom Hiszpanii, Holandii, Szwajcarii i Stanów Zjednoczonych w Berlinie i w Wiedniu, z prośbą o wręczenie jej Francji, Wielkiej Brytanii, Włochom, Japonii, Rosji, Rumunii i Serbii.

\section{0 grudnia}

Jules Ambon wręczył posłowi szwajcarskiemu w Paryżu odpowiedź Koalicji. Była to bezwzględna odmowa.

\section{ROK 1917}

\section{5 - 7 stycznia}

Zwycięstwa Niemców, Austriaków, Bułgarów w Dobrudży. W połowie stycznia zajęli południową część Mołdawii, całą Wołoszczyznę. Niemcy przejęli rumuńską naftę i pszenicę.

\section{0 stycznia}

Wypłynięcie misji alianckiejna parowcu „Kildonan Caste” do Piotrogrodu. 


\section{1 lutego}

Niemcy rozpoczęli na podstawie rozkazu cesarskiego nieograniczoną wojnę podmorską.

\section{1 marca}

Francja dała wolną rękę caratowi w sprawie przyszłości Polski.

\section{2/13 marca}

Posłowie Dumy prywatnie zebrali się i wybrali Tymczasowy Komitet Dumy Państwowej.

\section{5 marca}

Abdykacja Mikołaja II.

\section{6 marca}

Rosja stała się republiką.

\section{5 marca}

Rada Delegatów Robotniczych i Żołnierskich w Piotrogrodzie uchwaliła rezolucję o wyrzeczeniu się programu wszelkich aneksji i wszczęcia rokowań pokojowych „z robotnikami krajów nieprzyjacielskich”.

\section{6 kwietnia}

Stany Zjednoczone Ameryki Północnej przystąpiły do wojny po stronie Koalicji.

\section{6 kwietnia}

Lenin powrócił do Rosji.

\section{7 lipca}

Król Jerzy V na posiedzeniu Rady Tajnej zakomunikował o zmianie nazwy dynastii królewskiej - dom Sachsen-Coburg-Gotha - na Windsor. Tym samym rezygnuje z wszelkich godności i tytułów niemieckich.

\section{4 sierpnia}

Powstanie w Wielkiej Brytanii National War Aims Committee (Komitet Narodowych Celów Wojennych).

\section{4 sierpnia}

Wypowiedzenie przez Chiny wojny Niemcom.

\section{8 sierpnia - 13 września}

Jedenasta - ostatnia bitwa nad Isonzo. Włosi celu nie osiągnęli, drogi do Triestu nie zdobyli. W jedenastu bitwach Włosi ponieśli znaczące straty w ludziach - ponad 700 tys. rannych, zabitych, wziętych do niewoli.

\section{4 października}

Lord Alfred Milner i Leopold Amery przedłożyli Gabinetowi Wojennemu memoriał w sprawie Palestyny. Autorzy memoriału proponowali utworzenie w Palestynie siedziby narodowej dla „plemienia żydowskiego”. 


\section{5 października}

Rozstrzelanie Maty Hari, tancerki holendersko-malajskiej, oskarżonej o szpiegostwo.

\section{7 listopada}

Anglicy zdobyli Gazę. Zdobycie władzy przez bolszewików.

\section{7/8 listopada}

II Wszechrosyjski Zjazd Rad uchwalił Dekret o pokoju.

\section{7 listopada}

Anglicy zdobyli Jaffę.

\section{9 grudnia}

Anglicy zdobyli Jerozolimę.

\section{0 grudnia}

Rozejm Niemców i Austriaków z Rumunią.

\section{2 grudnia}

Pierwsze posiedzenie plenarne konferencji pokojowej w Brześciu. Udział w niej wzięli: Niemcy: sekretarz stanu Richard von Kuhlmann, generał Max Hoffmann; Austriacy: Otokar Czernin, hrabia Ferdynand Colloredo, ambasador Kajetan Merey, feldmarszałek-porucznik Maximilian Csicserics de Bacsany; Turcy: Halil Paşe i Achmed Nessimi Bey; Bułgarzy: Christo Popow i Petar Ganczew; przeciwników reprezentowali: Adolf Joffe (od 10 stycznia 1918 - Lew Trocki), Lew Kanieniew oraz Michaił Pokrowski.

\section{ROK 1918}

\section{8 stycznia}

Orędzie prezydenta Stanów Zjednoczonych Woodrowa Wilsona do Kongresu. W 14 punktach przedstawił program pokojowy. Proponuje, między innymi: Utworzenie Ligi Narodów; oswobodzenie i odbudowanie Belgii; wolność dla narodów Austro-Węgier; ewakuację wszystkich wojsk niemieckich i austriackich z zajętych ziem; autonomię wszystkim narodom nietureckim w Turcji; 13. punkt mówił o utworzeniu niepodległego państwa polskiego.

\section{4 stycznia}

Strajki w zakładach zbrojeniowych w Wiedniu.

\section{8 stycznia}

Strajki w zakładach zbrojeniowych w Berlinie.

\section{7 lutego}

Utrata mocy obowiązującej rozejmu pomiędzy państwami Czwórprzymierza a Rosją. Delegacja Rosji wyjechała z Brześcia. 


\section{3 lutego}

Oddziały Armii Czerwonej powstrzymały ofensywę niemiecką na Piotrogród.

\section{3 marca}

Podpisanie traktatu pokojowego w Brześciu Litewskim między Rosją Radziecką i państwami Czwórprzymierza (Niemcy, Austro-Węgry, Bułgaria, Turcja).

\section{0 marca}

Generał Foch obejmuje naczelne dowództwo nad wszystkimi armiami sprzymierzonych. Decyzja zapadła na konferencji, w której uczestniczyli: prezydent Republiki Francuskiej Raymond Poincaré, premier Francji Georges Clemenceau, premier Wielkiej Brytanii Dawid Lloyd George oraz lord Alfred Milner.

\section{1 marca - 6 kwietnia}

Rozpoczęcie niemieckiej ofensywy przeciwko pozycjom nieprzyjacielskim na linii od Cambrai do Saint-Quentin.

\section{1 marca}

Rozpoczęcie ofensywy niemieckiej na Wschodzie.

\section{9 - 29 kwietnia}

Druga ofensywa niemiecka we Flandrii. Niemcy odnieśli sukcesy, lecz bez rozstrzygnięć.

\section{9 kwietnia}

Ludendorff wydał rozkaz o zatrzymaniu ofensywy.

\section{7 maja}

Zawarcie traktatu pokojowego z Rumunią przez Niemcy, Austro-Węgry, Bułgarię i Turcję. Rumunia ma zapłacić dużą kontrybucję. Kapitał niemiecki przejął zagłębia naftowe.

\section{7 maja - 3 czerwca}

Trzecia ofensywa armii niemieckiej między Reims a Vanxaillon. Francuzi i Anglicy ponieśli wielkie straty. Niemcy opanowali 20-kilometrowy odcinek północnego brzegu Marny.

\section{9 - 14 czerwca}

Czwarta ofensywa niemiecka. Niemcom nie udało się zdobyć drogi do Compiègne.

\section{5 - 24 czerwca}

Nieudana ofensywa Austriaków nad dolną Piavą.

\section{8 lipca}

Kontrofensywa wojsk sprzymierzonych pod dowództwem Focha, którą rozpoczęli Francuzi. 


\section{2 sierpnia}

Francuzi zdobywają Soissons.

\section{8 - 11 sierpnia}

Przegrana przez Niemców bitwa pod Amiens. Odwrót Niemców.

\section{Poczatek września - 11 listopada}

Ciężkie walki na całym terytorium między wybrzeżem Flandrii i Saint-Mihiel.

\section{5 - 24 września}

Ofensywa Brytyjczyków, Greków, Francuzów, Serbów i Włochów w Macedonii. Klęska wojsk bułgarskich.

\section{9 września}

Przełamanie frontu tureckiego nad Jaffą. Oddziały angielskie wsparte przez Arabów zajęły Damaszek, Bejrut, Aleppo (walki trwały do końca października).

\section{0 września}

Zawarcie rozejmu z Bułgarią, na mocy którego musi ona opuścić terytoria zajęte wcześniej w Serbii i Grecji.

\section{4 października}

Na całym terytorium Bułgarii toczyły się walki aliantów. Do Koalicji przystąpiła Rumunia. Abdykacja cara Bułgarii, Ferdynanda I, na rzecz Borysa, następcy tronu.

\section{1 października}

Karol Liebknecht opuścił więzienie i stanął na czele Związku Spartakusa. Rewolucja w Wiedniu.

\section{4 października}

Przełamanie frontu austro-węgierskiego przez Włochów nad rzeką Piavą.

\section{8 października}

Proklamowanie niepodległej Czechosłowacji w Pradze.

\section{1 października}

Rozejm angielsko-turecki w Mudro. Turcja opuszcza Arabię, Mezopotamię, Syrię, Armenię, część Cylicji. Zgoda na tymczasowe przekazanie Koalicji Konstantynopol i cieśniny Bosfor i Dardanele.

\section{9 - 31 października}

Początek ruchów rewolucyjnych w miastach portowych Niemiec.

\section{1 listopada}

Serbowie zajęli Belgrad, Włosi - Albanię. 


\section{3 listopada}

Kapitulacja Austro-Węgier. Powstanie marynarzy w Kilonii. Tworzenie się Rad Robotniczych i Żołnierskich. Rewolucja rozszerza się na duże miasta niemieckie.

\section{8 listopada}

Marszałek Foch w towarzystwie szefa sztabu generała Maxima Weyganda, brytyjskiego admirała sir Westera Wemyssa i admirała George’a Hopea $\mathrm{w}$ wagonie salonowym rozpoczęli posiedzenie $\mathrm{z}$ delegacją niemiecką: Matthiasem Erzbergerem, Hansem von Winterfeldtem, Ernstem Vanselowem, która prosiła o rozejm. Oto jego warunki: ewakuacja Belgii, Francji, Alzacji i Lotaryngii. Ewakuacja lewego brzegu Renu i przyczółków mostowych. Wydanie 5 tys. armat, 30 tys. karabinów maszynowych, 3 tys. moździerzy, 5 tys. lokomotyw, 150 tys. wagonów, 2 tys. samolotów, 5 tys. samochodów. Wydanie 100 łodzi podwodnych, 8 lekkich krążowników, 6 pancerników. Pozostałe jednostki mają być rozbrojone i znajdować się pod dozorem. Utrzymanie blokady. Zrzeczenie się kolonii w Afryce.

\section{8 listopada}

Abdykacja cesarza. Utworzenie nowego rządu pod prezesurą Friedricha Eberta.

\section{9 listopada}

Matthias Erzberger otrzymał z Berlina telegram, podpisany przez Hindenburga, że rozejm należy zawrzeć za wszelką cenę. Niemcy warunki postawione przyjęli.

\section{0 listopada}

Rozejm wszedł w życie o godz. $11 \mathrm{w}$ południe. Cesarz Karol Habsburg zrzekł się władzy i wyjechał do Szwajcarii. Nastąpił rozpad Austro-Węgier.

\section{Sprawa polska w czasie I wojny światowej na ziemiach polskich}

\section{ROK 1914}

\section{6 sierpnia}

Wczesnym rankiem I Strzelecka Kompania Kadrowa pod dowództwem Józefa Piłsudskiego wyruszyła z Krakowa do Królestwa. Przekroczyła granicę austriacko-rosyjską, usunęła słupy graniczne i kierowała się w stronę Miechowa.

\section{0 sierpnia}

Komisja Skonfederowanych Stronnictw podporządkowała się Rządowi Narodowemu i uznała się za jego przedstawicielstwo w Galicji. 


\section{2 i 13 sierpnia}

W Wiedniu Juliusz Leo, Leon Biliński, Zdzisław Morawski, Michał Bobrzyński uzgodnili z szefem sztabu Conradem von Hotzendorfem, Leopoldem Berchtoldem i Fridrichem von Georgiem sprawę tworzenia polskiego wojska ochotniczego i jego reprezentacji politycznej.

\section{4 sierpnia}

Wielki książę Mikołaj Mikołajewicz wydał odezwę, w której ogłasza plan zjednoczenia ziem polskich pod berłem cara Rosji.

\section{6 sierpnia}

Zawiązanie Naczelnego Komitetu Narodowego (NKN) jako najwyższej instancji w sprawach wojskowych, skarbowych, politycznych organizacji zbrojnych sił polskich stronnictw Galicji.

\section{Koniec sierpnia}

Powstanie Legionu Zachodniego i Legionu Wschodniego pod dowództwem generałów austriackich - Polaków.

\section{4 i 5 września}

Złożenie przysięgi przez żołnierzy Legionu Zachodniego, według formuły austriackiego pospolitego ruszenia. Żołnierze Legionu Wschodniego w większości odmówili złożenia przysięgi na „wierność cesarzowi Austrii i apostolskiemu królowi Węgier”.

\section{2 września}

Utworzenie w Królestwie Polskim tajnej organizacji wojskowej - Polskiej Organizacji Wojskowej (POW) pod komendą Józefa Piłsudskiego.

\section{0 września}

Legion Wschodni został rozwiązany.

\section{Listopad}

Utworzenie w Warszawie Komitetu Narodowego Polskiego - przedstawicielstwa polskich kół prorosyjskich.

\section{ROK 1915}

\section{4 stycznia}

Ukonstytuowanie się w Warszawie Komisji Szkół Wyższych.

\section{Maj}

Początek odwrotu Rosjan z ziem polskich. W odwrocie żołnierze rosyjscy niszczyli wszystko, co napotkali po drodze. Palili wsie, dwory, lasy, zboża na pniu. Mieszkańców wyrzucali ze swych siedzib i gnali na wschód.

\section{Lipiec}

Ochrona carska aresztowała około 3 tys. osób, głównie młodzież, i wywiozła bez aktu oskarżenia, zarzucając im spisek niepodległościowy.

\section{Polonistyka. Innowacje}




\section{7 lipca}

Komitet Warszawy uzyskał od władz rosyjskich zezwolenie na utworzenie Straży Obywatelskiej, jej celem było objęcie straży porządkowej w mieście.

\section{4 sierpnia}

Straż Obywatelska objęła posterunki w stolicy. Wyjście Rosjan z Warszawy i oddanie zarządu miasta księciu Zdzisławowi Lubomirskiemu, prezesowi Komitetu Centralnego i Komitetu Warszawskiego.

\section{5 sierpnia}

Niemcy zajęli Warszawę. Komitet Obywatelski rozpoczął czynności nieistniejącego państwa polskiego w dziedzinie sądownictwa.

\section{0 sierpnia}

W pałacu Paca i pałacu Krasińskich odbyła się pierwsza sesja Sądu dwóch instancji - Trybunału oraz Sądu Głównego. Od lat 40 - po raz pierwszy - wypowiedziano słowa: „posiedzenie sądu otwarte”.

\section{5 sierpnia}

Przyjazd Piłsudskiego do Warszawy. Celem było wyjaśnienie decyzji o wstrzymaniu werbunku do POW.

\section{3 sierpnia}

$\mathrm{Na}$ wniosek prezydenta Warszawy, Zdzisława Lubomirskiego, Komitet Obywatelski wprowadził obowiązkowe powszechne nauczanie dzieci i młodzieży.

\section{4 sierpnia}

Rozporządzeniem cesarskim utworzono niemieckie generał-gubernatorstwo z siedzibą w Warszawie. Generał-gubernator podlegał cesarzowi i wykonywał „najwyższą władzę wojskową i cywilną”. Austriacy utworzyli generał-gubernatorstwo z siedzibą w Kielcach, a od $1 \mathrm{X}$ w Lublinie.

\section{4 września}

Mianowanie niemieckiego generał-gubernatora w Warszawie, generała piechoty Hansa von Beselera. Austriacy mianowali początkowo generał-gubernatorem generał-majora barona Ericha Dillera, w maju 1916 zmienił go na tym stanowisku Karl Kuk.

\section{1 września}

Komitet Obywatelski jako Zarząd Miasta przywrócił Warszawie, usunięty w roku 1870 przez okupacyjne władze rosyjskie, tytuł stolicy i nazwał, jak dawniej, miastem stołecznym.

\section{5 listopada}

Uroczyste otwarcie Uniwersytetu i Politechniki w Warszawie w obecności trzech żyjących jeszcze profesorów dawnej Szkoły Głównej. Rektorem 
Uniwersytetu został znakomity lekarz - pediatra Józef Brudziński. Zgoda na otwarcie wyższych uczelni wiązała się z pozyskaniem przychylności Polaków do celów politycznych.

\section{8 grudnia}

Utworzenie w Warszawie Centralnego Komitetu Narodowego, działającego we współpracy z państwami centralnymi.

\section{ROK 1916}

\section{1 i 12 sierpnia}

Kanclerz Rzeszy i minister spraw zagranicznych Austro-Węgier na konferencji w Wiedniu ustalili podstawy rozwiązania sprawy polskiej: utworzenie samodzielnego królestwa polskiego z monarchią dziedziczną i ustrojem konstytucyjnym.

\section{4 października}

Wydanie rozporządzenia przez Beselera „o zwalczaniu wstrętu do pracy” oraz dotkliwe kary za uchylanie się od pracy. Sprawa dotyczyła robotników, którzy mieli być wysyłani do Niemiec. Polacy odmawiali wyjazdu.

\section{8 października}

Na konferencji austriacko-niemieckiej w Pszczynie postanowiono ogłosić „możliwie najszybciej” samodzielne państwo polskie, z armią, którą mieli organizować Niemcy. Intencja była czytelna - pozyskanie wojska.

\section{5 listopada}

Ogłoszenie Aktu 5 listopada przez cesarza Niemiec i Austro-Węgier. Akt uwydatnił międzynarodowy charakter sprawy polskiej. Franciszek Józef wydał dekret o wyodrębnieniu Galicji.

\section{2 listopada}

Beseler wydaje rozporządzenie o utworzeniu Rady Stanu i Sejmu w Królestwie Polskim. Społeczeństwo polskie przyjęło ogłoszenie negatywnie.

\section{6 grudnia}

Beseler i Kuk ogłosili, iż „z najwyższego rozkazu” w Warszawie utworzona zostanie Tymczasowa Rada Stanu. Miała ona charakter wyłącznie opiniotwórczy (25 sierpnia 1917 wszyscy członkowie złożyli dymisję).

\section{2 grudnia}

Propozycja państw centralnych w sprawie wszczęcia rokowań pokojowych.

\section{ROK 1917}

\section{7 marca}

Orędzie Rady Delegatów Robotniczych i Żołnierskich w Piotrogrodzie o prawach Polaków do odbudowy niepodległego państwa.

\section{Polonistyka. Innowacje}




\section{4 czerwca}

Dekret prezydenta Francji o utworzeniu armii polskiej we Francji.

\section{9 - 11 lipca}

Większość legionistów odmówiła (w myśl zaleceń Piłsudskiego) podporządkowania się zarządzeniom Beselera i złożenia przysięgi, nakazującej posłuszeństwo cesarzowi niemieckiemu. Był to tzw. kryzys przysięgowy. Legioniści z zaboru rosyjskiego zostali umieszczeni w obozach jenieckich w Beniaminowie i Szczypiornie; z zaboru austriackiego wysłani na front włoski.

\section{1/22 lipca}

Aresztowanie i wywiezienie do Magdeburga Józefa Piłsudskiego i Kazimierza Sosnkowskiego.

\section{6 sierpnia} Stanu.

Komenda POW wypowiedziała posłuszeństwo Tymczasowej Radzie

\section{1 - 12 sierpnia}

Utworzenie na zjeździe w Lozannie Komitetu Narodowego Polskiego (KNP) z siedzibą w Paryżu, pod prezesurą Romana Dmowskiego. Było to przedstawicielstwo polityczne Polski na Zachodzie. KNP za „oficjalną organizację polską" 20 września uznała Francja, 15 października Wielka Brytania, 30 października Włochy, USA - 10 listopada.

\section{5 października}

Dwaj cesarze powołali Radę Regencyjną w osobach: kardynała Aleksandra Kakowskiego, księcia Zdzisława Lubomirskiego oraz ziemianina Józefa Ostrowskiego (byłego członka rosyjskiej Rady Państwa).

\section{7 listopada}

Powołanie pierwszego królewsko-polskiego prezydenta ministrów Jana Kucharzewskiego (dopiero 7 grudnia dokonano nominacji).

\section{ROK 1918}

\section{8 stycznia}

Prezydent Stanów Zjednoczonych Ameryki, Woodrow Wilson, ogłosił czternastopunktowe orędzie. 13. punkt zapowiadał utworzenie niepodległego państwa polskiego.

\section{3 czerwca}

Wielka Brytania, Francja, Włochy ogłaszają deklarację w sprawie przywrócenia niepodległości Polski.

\section{9 sierpnia}

Dekret Rady Komisarzy Ludowych o anulowaniu traktatów rozbiorowych. 


\section{8 października}

W Krakowie powstaje Polska Komisja Likwidacyjna - tymczasowa władza dla Galicji.

\section{6 listopada}

Utworzenie Republiki Tarnobrzeskiej.

\section{7 listopada}

Powstanie Tymczasowego Ludowego Rządu Republiki Polskiej w Lublinie.

\section{0 listopada}

Przyjazd Piłsudskiego z Magdeburga do Warszawy.

\section{1 listopada}

Warszawa wolna od okupacji niemieckiej.

\section{4 listopada}

Rada Regencyjna dekretem się rozwiązała i przekazała obowiązki względem „narodu polskiego” Józefowi Piłsudskiemu. 
